\title{
Physical and Physiological Profiles of Brazilian Jiu-Jitsu Athletes: a Systematic Review
}

\author{
Leonardo Vidal Andreato ${ }^{1 *}$, Francisco Javier Díaz Lara², Alexandro Andrade ${ }^{1}$ \\ and Braulio Henrique Magnani Branco 3,4
}

\begin{abstract}
Background: Brazilian jiu-jitsu is a grappling combat sport that has intermittency as its core element; in other words, actions of high, moderate and low intensity are interspersed during matches, requiring a high level of conditioning to support optimal levels of performance for the total match time. The athletes perform from four to six matches during a day of competition, and this number may increase if the open-class competition, which is held parallel to the competition by weight class, is considered. This systematic review examined the physical and physiological profiles of Brazilian jiu-jitsu athletes.

Methods: Only scientific researches dealing with the major fitness components of Brazilian jiu-jitsu athletes (i.e. body composition and somatotype, aerobic and anaerobic profiles, muscular strength and power) and using accepted methods that provided relevant practical applications for a Brazilian jiu-jitsu athlete's fitness training and/ or performance were included in the current review. A computer literature search was carried out of the PubMed, ISI Web of Knowledge, SportDiscus and Scopus databases (up to January 2016).

Results: The database research generated 205 articles. After the application of inclusion and exclusion criteria, 58 studies were included for the present systematic review. A total of 1496 subjects were involved in all the selected investigations.

Conclusions: Body fat is generally low for these athletes and the mesomorphic component is predominant. The different studies showed $\mathrm{VO}_{2 \max }$ values between 42 and $52 \mathrm{~mL} / \mathrm{kg} / \mathrm{min}$, and it seems that aerobic fitness does not discriminate among Brazilian jiu-jitsu athletes of different competitive levels. There is a lack of scientific studies that have investigated anaerobic responses both in lower and upper limbs. Maximal dynamic, isometric and endurance strength can be associated with sporting success in Brazilian jiu-jitsu athletes. Although decisive actions during Brazilian jiu-jitsu matches are mainly dependent on muscular power, more specific studies are necessary to describe it. Studies involving the female sex should be conducted. In addition, further research is needed to analyse whether there are differences between sex, belt ranks and competitive level, and among the different weight categories for different variables.
\end{abstract}

Keywords: Combat sports, Physical fitness, Physical evaluation

\footnotetext{
* Correspondence: vidal.leo@hotmail.com

${ }^{1}$ Sciences Center of Health and Sport, State University of Santa Catarina,

Florianopolis, Brazil

Full list of author information is available at the end of the article
} 


\section{Key Points}

- Brazilian jiu-jitsu athletes had low body fat without differences between novices and experts or between elite and non-elite athletes.

- Aerobic power was similar to that of other grappling combat sports and did not seem to be influenced by the Brazilian jiu-jitsu athlete's competitive level.

- Experience and competitive level seem to influence an athlete's flexibility responses as experienced athletes had greater flexibility than beginners and elite athletes showed more flexibility than non-elite athletes.

\section{Background}

In the last decade in particular, there has been a significant rise in the popularity of Brazilian jiu-jitsu. Part of this is due to the success of Brazilian jiu-jitsu athletes in mixed martial arts events [1]. In national and international competitions of the International Brazilian Jiu-Jitsu Federation, there are nine weight categories for males $(<57.5,64,70$, $76,82.3,88.3,94.3,100.5$ and $<100.5 \mathrm{~kg}$ ) and eight weight categories for females $(<48.5,53.5,58.5,64,69,74,79.3$ and $<79.3 \mathrm{~kg}$ ). Brazilian jiu-jitsu competitions are also divided according to athletes' age as follows: juvenile (15-17 years of age), adult ( $>18$ years of age) and master ( $>30$ years of age) [2]. The duration of matches takes these variables into account and can vary from $5 \mathrm{~min}$ for white belts to $10 \mathrm{~min}$ for black belts [2].

Athletes start fighting from a standing position, but most of the combat takes place in groundwork [3]. The aim of the sport is to make your opponent give up the combat by means of choke, joint locks (wrist, elbow, knee and ankle locks) or pressure techniques, but when there is no submission the matches are decided by the scoring of specific techniques (takedown, guard pass, mount, back mount, back control, knee on belly and sweep), and in the event of a draw by the referee's decision [2].

The main characteristic of Brazilian jiu-jitsu is intermittency [4]. An athlete has to perform on average four to six matches to become champion in the main competitions of the modality [1, 4]. Various capacities and physical skills are required during a jiu-jitsu match, and thus, the athletes need to be in excellent physical condition to support the demands of the training and consequently the matches [5]. In this sense, as examples, we can cite aerobic power, which collaborates to maintain a high intensity throughout the match, delay fatigue and achieve a better/ faster recovery between matches [6]; muscle strength, which is used for both attack and defence; muscle power, used in the application of throwing techniques or in some specific movements of groundwork actions (sweeps and guard pass); muscular endurance for maintaining grip on the opponent's gi (specific apparel for training) when there is a gripping dispute, to dominate the opponent and apply techniques and maintain positions; the reaction time used to dodge and/or anticipate the opponent's attacks or take advantage of opportune moments for the application of attacks; and flexibility, which collaborates in specific situations of attack or defence [1,7]. Also, due to the fact that athletes are divided according to body mass, the fighters are required to present a low percentage of body fat, with greater muscle development, predominantly a mesomorphic profile, which is associated with competitive success, since athletes often reduce their body mass to compete $[8,9]$.

Given this dynamic of the matches, the athletes are required to possess a high level of fitness. In this regard, for an organization and training prescription with greater specificity, it is essential to know the physical and physiological profiles of the sport's athletes. Other combat sports such as judo [10], wrestling [11], amateur boxing [12], taekwondo [13] and karate [14] have had this profile very well described in the literature.

However, to date, there have been no in-depth review papers that synthesize the physical and physiological characteristics of Brazilian jiu-jitsu athletes. A review of Brazilian jiu-jitsu athletes' characteristics could improve the knowledge of coaches, and strength and conditioning of trainers, concerning the physical and physiological profiles needed to reach a high level of performance in this combat sport. Thus, the aim of the present study is to provide a comprehensive review that will help scientists, coaches and athletes to better understand the physical and physiological profile requirements of Brazilian jiu-jitsu. Finally, it is important to point out that the current systematic review centred on analysing the studies involving the gi or kimono in Brazilian jiu-jitsu athletes.

\section{Methods \\ Searches}

A computer literature search was carried out of the PubMed, ISI Web of Knowledge, SportDiscus and Scopus databases (up to January 2016) for English-language, peer-reviewed articles. The keywords used were as follows: "Brazilian jiu-jitsu", "Brazilian jiu-jitsu" AND "performance" OR "physical fitness" OR "physiology" OR "body composition" OR "somatotype" OR "aerobic fitness" OR "anaerobic fitness" OR "strength" OR "muscle power" OR "muscular endurance" OR "flexibility" OR "reaction time" OR "speed" OR "agility". Articles published in English, Portuguese or Spanish were included. References (articles, books and congress abstracts) from the original studies were searched for further relevant investigations.

This systematic review is reported in accordance with Meta-analysis Of Observational Studies in Epidemiology (MOOSE) [15]. 


\section{Study Inclusion and Exclusion Criteria}

Only scientific researches dealing with the major fitness components of Brazilian jiu-jitsu athletes (body composition and somatotype, aerobic and anaerobic profiles, muscular strength, muscle power, muscle endurance, flexibility, reaction time, speed and agility) and using accepted methods that provided relevant practical applications for a Brazilian jiu-jitsu athlete's fitness training and/or performance were included in the current review. Besides, just studies involving athletes (male and female) were added. However, one study involving practitioners was added due to high number of subjects [16].

\section{Assessment of Risk of Bias}

For the present systematic review, two reviewers independently analysed the titles and abstracts of the articles retrieved from the literature search and reviewed the full text of the published articles. Any disagreements between the reviewers regarding study inclusion were resolved by a third investigator.

\section{Results}

\section{Search Results}

Figure 1 shows a flow chart summarizing the results of the systematic search that identified a total of 205 searches in the electronic databases PubMed, Web of Knowledge, Scopus and SportDiscus. After having added relevant studies from other sources (e.g. reference lists from original and review articles) and after having screened the articles by title, removed duplicates and excluded ineligible articles, 58 studies remained and were included in the present study. A total of 1496 subjects participated in the 58 studies.

\section{Discussion \\ Body Composition}

It is crucial to know an athlete's body composition in combat sport modalities in order to control and define the weight category. In the adult category, the weight classes range from $<48.5$ to $>84.3 \mathrm{~kg}$ with kimono for females, and $<57.5$ to $>100.5 \mathrm{~kg}$ with kimono for male athletes [2]. Thus, it is impracticable to establish a fat percentage profile for all weight classes. In addition, in other combat sports such as judo, a higher body fat percentage is negatively correlated with performance in locomotion and technical entrance activities $[17,18]$.

In the present study (Table 1), a higher variation in the body fat percentage was observed, ranging from 5.3 to $19.9 \%$ for male athletes. However, the average values observed were of $\sim 12 \%$. Only two studies were found involving female athletes and the results showed average

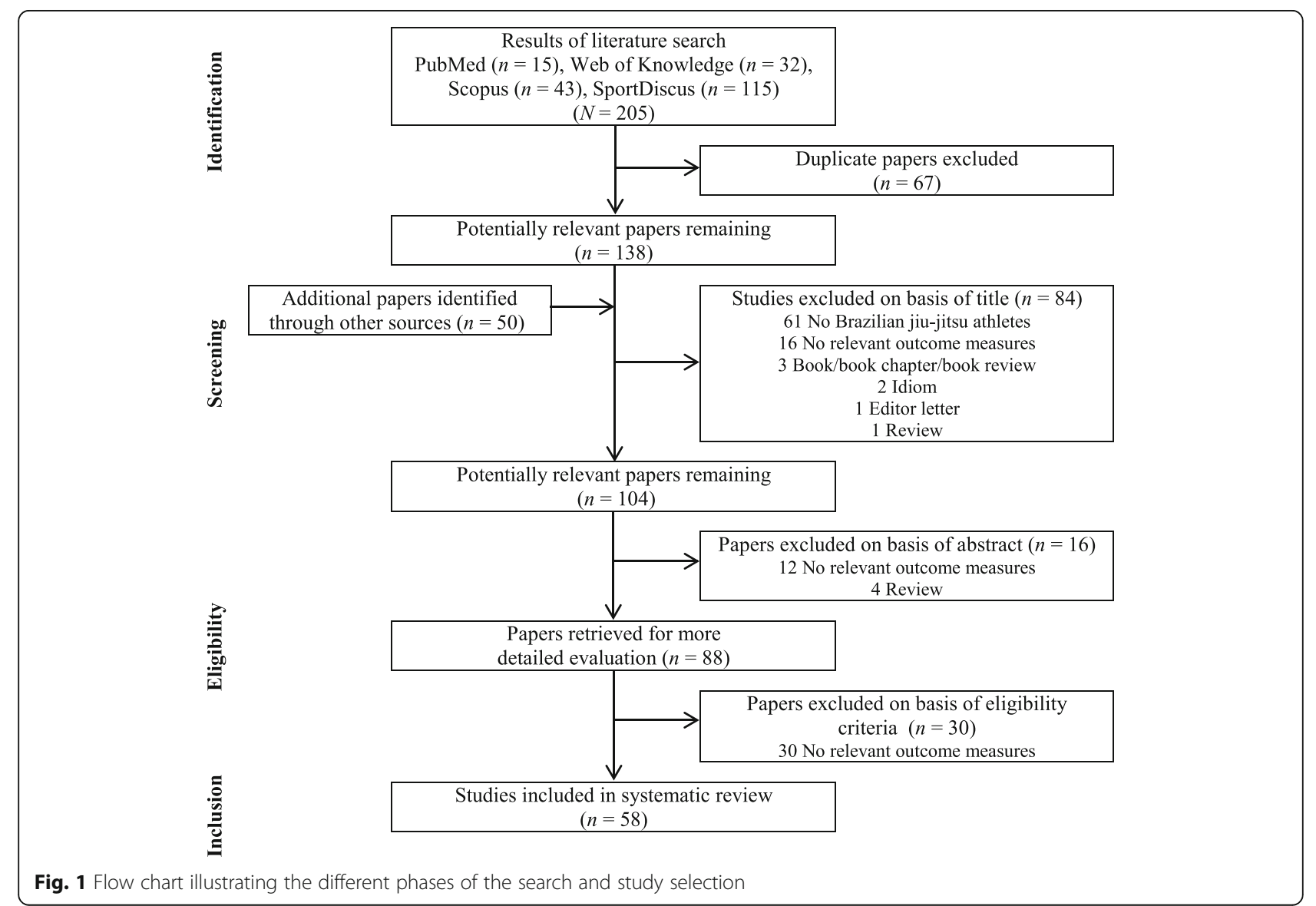


Table 1 Body fat percentage of Brazilian jiu-jitsu athletes (data are presented as the mean \pm SD)

\begin{tabular}{|c|c|c|c|c|}
\hline Athlete characteristics ( $n$ ) & $\begin{array}{l}\text { Body mass } \\
(\mathrm{kg})\end{array}$ & $\begin{array}{l}\text { Body fat } \\
(\%)\end{array}$ & $\begin{array}{l}\text { Method } \\
\text { (Prediction equation reference) }\end{array}$ & References \\
\hline \multicolumn{5}{|l|}{ Male } \\
\hline High level athletes $(n=14)$ & $71.3 \pm 9.1$ & $8.5 \pm 1.5$ & Carter $[84]$ & Diaz-Lara et al. [85] \\
\hline High level athletes $(n=8)$ & $76 \pm 10$ & $11.2 \pm 3.0^{\mathrm{a}}$ & Lohman [86] & Marinho et al. [25] \\
\hline State level athletes $(n=10)$ & $72 \pm 5$ & $14.8 \pm 3.0$ & & \\
\hline $\begin{array}{l}\text { Athletes of different competitive levels_-brown } \\
\text { and black belt }(n=10)\end{array}$ & $81.8 \pm 7.4$ & $13.0 \pm 4.8$ & Jackson and Pollock [87] & Andreato et al. [39] \\
\hline High level athletes $(n=26)$ & $75.4 \pm 9.7$ & $9.5 \pm 2.1$ & Bioimpedance-Moon et al. [88] & Diaz-Lara et al. [89] \\
\hline State level athletes_-blue to black belt $(n=15)$ & $82.2 \pm 11.9$ & $14.6 \pm 5.6$ & Jackson and Pollock [87] & Follmer et al. [90] \\
\hline Athletes of different competitive levels $(n=9)$ & $73.3 \pm 9.7$ & $6.8 \pm 2.1$ & Jackson and Pollock [87] & Mazzoccante et al. [35] \\
\hline State level athletes $(n=9)$ & $77.4 \pm 24.5$ & $16.5 \pm 7.1$ & Jackson and Pollock [87] & Ribeiro et al. [36] \\
\hline State level athletes $(n=9)$ & $84.6 \pm 19.9$ & $16.1 \pm 5.6$ & & \\
\hline Practitioners $(n=136)$ & $81.8 \pm 13.1$ & $16.2 \pm 6.7$ & Jackson and Pollock [87] & Schwartz et al. [16] \\
\hline High level athletes_-brown and black belt ${ }^{\mathrm{b}}$ & $77.9 \pm 6.8$ & $7.4 \pm 2.7$ & Jackson and Pollock [87] & Silva et al. [68] \\
\hline Practitioners_-blue and purple belt ${ }^{\mathrm{b}}$ & $76.5 \pm 8.7$ & $6.5 \pm 1.7$ & & \\
\hline High level athletes_-purple to black belt & & & Kerr [91] & Báez et al. [26] \\
\hline Pass fighter $(n=10)$ & $75.0 \pm 8.9$ & $18.4 \pm 2.5$ & & \\
\hline Guard fighter $(n=15)$ & $75.9 \pm 11.9$ & $19.9 \pm 2.5^{c}$ & & \\
\hline All $(n=25)$ & $75.6 \pm 10.6$ & $19.3 \pm 2.5$ & & \\
\hline High level athletes $(n=20)$ & $81.6 \pm 5.4$ & $7.1 \pm 5.4$ & NR & Brandão et al. [22] \\
\hline Practitioners $(n=10)$ & $83.3 \pm 3.8$ & $7.8 \pm 2.5$ & NR & \\
\hline State level athletes $(n=20)$ & $68.1+8.5$ & $12.0+4.3$ & Jackson and Pollock [87] & Carmo et al. [92] \\
\hline High level athletes & & & Bioimpedance—Moon et al. [88] & Diaz-Lara et al. [20] \\
\hline Novice-white to blue belt $(n=24)$ & $75.7 \pm 9.3$ & $9.3 \pm 3.7$ & & \\
\hline Expert-purple to black belt $(n=32)$ & $77.4 \pm 11.3$ & $9.1 \pm 4.6$ & & \\
\hline Brown or black belt $(n=10)$ & $83.8 \pm 12.1$ & $16.1 \pm 10.1$ & Jackson and Pollock [87] & Joel et al. [52] \\
\hline Brown or black belt $(n=10)$ & $83.1 \pm 10.1$ & $16.6 \pm 8.0$ & & \\
\hline Practitioners-men $(n=8)$ & $78.9 \pm 7.9$ & $19.4 \pm 5.2$ & NR & Lorenço-Lima et al. [93] \\
\hline Athletes of different competitive levels $(n=10)$ & $70.3 \pm 5.9$ & $6.8 \pm 2.4$ & Jackson and Pollock [87] & Mazzoccante et al. [37] \\
\hline High level athletes $(n=49)$ & $77.3 \pm 6.5$ & $15.7 \pm 4.0$ & Bioimpedance & Pietraszewska et al. [94] \\
\hline High level athletes $(n=10)$ & $70.0 \pm 3.3$ & $14.1 \pm 2.9$ & Thorland et al. [95] & Pinho-Júnior et al. [96] \\
\hline Practitioners - purple to black (NR) & $78.7 \pm 7.9$ & $9.5 \pm 1.9$ & NR & Tinsley et al. [97] \\
\hline High level athletes $(n=11)$ & $83.1 \pm 8.7$ & $10.3 \pm 2.6$ & Jackson and Pollock [87] & Andreato et al. [8] \\
\hline Athletes of different competitive levels $(n=12)$ & $75.4 \pm 8.8$ & $9.2 \pm 2.4$ & Jackson and Pollock [87] & Andreato et al. [98] \\
\hline Athletes of different competitive levels & & & Tipton and Oppliger [99] & Arruda et al. [99] \\
\hline Feather $(n=3)$ & $69.8^{\mathrm{d}}$ & $10.5^{\mathrm{d}}$ & & \\
\hline Light $(n=1)$ & 47.0 & 5.3 & & \\
\hline Middle $(n=3)$ & $81.6^{d}$ & $9.8^{d}$ & & \\
\hline Medium heavy $(n=4)$ & $87.6^{d}$ & $12.5^{\mathrm{d}}$ & & \\
\hline Heavy $(n=1)$ & 90.0 & 14.6 & & \\
\hline Ultra heavy $(n=2)$ & $95.0^{\mathrm{d}}$ & $14.5^{\mathrm{d}}$ & & \\
\hline All $(n=14)$ & $82.8 \pm 9.1$ & $11.4 \pm 3.6$ & & \\
\hline Athletes of different competitive levels $(n=155)$ & $78.2 \pm 8.5$ & $15.9 \pm 6.1$ & Thorland et al. [95] & Brito et al. [9] \\
\hline High level athletes $(n=9)$ & $68.0 \pm 2.8$ & $12.7 \pm 3.5$ & Thorland et al. [95] & Santos et al. [100] \\
\hline State level athletes $(n=21)$ & $78.1 \pm 9.4$ & $14.3 \pm 4.8$ & NR & Souza-Junior et al. [101] \\
\hline
\end{tabular}


Table 1 Body fat percentage of Brazilian jiu-jitsu athletes (data are presented as the mean \pm SD) (Continued)

\begin{tabular}{|c|c|c|c|c|}
\hline Beginner athletes—white and blue belt $(n=7)$ & $74.9 \pm 5.9$ & $8.7 \pm 3.8$ & Jackson and Pollock [87] & Coswig et al. [21] \\
\hline Experienced athletes-more than purple belt $(n=7)$ & $79.0 \pm 4.1$ & $9.1 \pm 3.0$ & Jackson and Pollock [87] & \\
\hline High level athletes $(n=7)$ & $77.9 \pm 3.5$ & $9.0 \pm 2.6$ & Jackson and Pollock [87] & Andreato et al. [23] \\
\hline State level athletes $(n=7)$ & $72.2 \pm 25.0$ & $9.1 \pm 3.1$ & Jackson and Pollock [87] & \\
\hline High level athletes $(n=8)$ & $79.4 \pm 9.5$ & $8.4 \pm 2.3$ & Jackson and Pollock [87] & Gomes et al. [24] \\
\hline State level athletes $(n=5)$ & $72.4 \pm 7.7$ & $9.8 \pm 2.4$ & Jackson and Pollock [87] & \\
\hline High level athletes $(n=106)$ & $76.0 \pm 15.2$ & $15.8 \pm 6.1$ & Thorland et al. [95] & Roas et al. [102] \\
\hline State level athletes_-purple to black belt $(n=5)$ & $93.8 \pm 13.7$ & $19.9 \pm 4.3$ & Jackson and Pollock [87] & Rigatto [103] \\
\hline State level athletes_-purple to black belt $(n=7)$ & $80.4 \pm 16.6$ & $12.2 \pm 5.7$ & & \\
\hline High level athletes $(n=7)$ & $78.9 \pm 12.2$ & $9.8 \pm 4.2$ & Guedes and Guedes [104] & Del Vecchio et al. [3] \\
\hline \multicolumn{5}{|l|}{ Female } \\
\hline Practitioners $(n=8)$ & $56.3 \pm 10.0$ & $24.2 \pm 3.6$ & & Lorenço-Lima et al. [93] \\
\hline Athletes $(n=14)$ & $61.0 \pm 11.5$ & $19.3 \pm 6.3$ & Slaughter et al. [105] & Roas et al. [102] \\
\hline
\end{tabular}

NR not reported

Pass fighter: athlete fighting passing the guard (rather than playing above)

Guard fighter: athlete fighting inside the guard (prefers to fight underneath)

${ }^{a}$ Significant difference from non-elite group from the same study

${ }^{b}$ Did not report the number for each group, in total the study included 28 subjects

'Significant difference versus pass fighter group from the same study

${ }^{\mathrm{d}}$ Only mean value

values of 19.3 and $24.2 \%$ body fat percentage. It is worth emphasizing that the protocols used in order to estimate the percentage of body fat in Brazilian jiu-jitsu athletes were generic, or may exhibit variation in the method selected; therefore, comparisons between athletes of different studies should be made with caution.

In judo, it has been observed that there are gradual increases in body fat with the increase in the weight class [10]. In Brazilian jiu-jitsu, this phenomenon also seems to occur, despite the small number of subjects in the single study that showed the body fat values of athletes from different categories [19].

Two studies found no differences between novice and expert athletes when comparing body composition [20, $21]$. When comparing elite and non-elite athletes, three studies [22-24] found no differences, but one study [25] found differences in body composition, with a lower body fat percentage for the elite group. However, an interesting fact observed was that the fighting style may require different biotypes, since a pass fighter had a lower percentage of fat than a guard fighter [26]. In this sense, research that considers the association among body fat percentage, technical actions and fighting style (passer and guard player) may be relevant for the training prescription of Brazilian jiu-jitsu athletes.

\section{Somatotype}

It has been suggested that somatotype and sports success are positively correlated. In grappling sports (e.g. judo, wrestling and Brazilian jiu-jitsu), the mesomorphy component has been highlighted as the most relevant for performance $[8,10,11]$, and one that also allows discrimination of athletes from different performance levels [27, 28].

The systematic search indicated that only four studies examined the somatotype of Brazilian jiu-jitsu athletes (Table 2). However, in all of them the mesomorphic

Table 2 Somatotype of Brazilian jiu-jitsu athletes (data are presented as the mean \pm SD)

\begin{tabular}{|c|c|c|c|c|}
\hline Athlete characteristics $(n)$ & Endomorphy & Mesomorphy & Ectomorphy & Reference \\
\hline \multicolumn{5}{|l|}{ Male } \\
\hline High level athletes & & & & Báez et al. [26] \\
\hline Pass fighter $(n=10)$ & $2.3 \pm 0.6$ & $7.0 \pm 1.2$ & $1.3 \pm 0.6$ & \\
\hline Guard fighter $(n=15)$ & $2.2 \pm 0.7$ & $5.9 \pm 0.9^{a}$ & $2.1 \pm 0.9 \mathrm{a}$ & \\
\hline All $(n=25)$ & $2.2 \pm 0.7$ & $6.3 \pm 1.1$ & $1.8 \pm 0.9$ & \\
\hline High level athletes $(n=49)$ & $2.1 \pm 0.6$ & $5.8 \pm 1.0$ & $2.0 \pm 0.8$ & Pietraszewska et al. [94] \\
\hline High level athletes $(n=11)$ & $3.0 \pm 0.8$ & $5.5 \pm 1.0$ & $1.7 \pm 0.6$ & Andreato et al. [8] \\
\hline High level athletes $(n=7)$ & $3.2 \pm 1.6$ & $7.9 \pm 1.4$ & $1.7 \pm 0.6$ & Del Vecchio et al. [3] \\
\hline
\end{tabular}

${ }^{\mathrm{a}}$ Significant difference versus pass fighter group from the same study 
component was predominant (range 5.5 to 7.9), a fact that coincides with previous studies that evaluated body composition, indicating a good muscle development of the athletes in other grappling sports $[10,11]$. In addition, in one of these studies [26] the athletes were divided based on their fighting style and it was observed that pass fighters showed higher values of mesomorphy and lower values of ectomorphy than guard fighters. Based on empirical observations, these results were to be expected, since it has been observed that there is a greater use of strength in guard pass work, and that athletes with ectomorphic characteristics tend to have more facility in performing guard works. However, further studies in this direction are needed to confirm these findings.

\section{Aerobic Profile}

In combat sports, high levels of aerobic power and capacity allow athletes to maintain a high intensity throughout the match, contribute to sustaining effort for the entire combat duration and help in achieving a better/ faster recovery between matches $[6,29,30]$.

For aerobic power, $\mathrm{VO}_{2 \max }$ values were observed between 42 and $52 \mathrm{~mL} / \mathrm{kg} / \mathrm{min}$ in males. In fact, there are still a few studies that have investigated the aerobic profile in Brazilian jiu-jitsu athletes. Only four studies employed the gold-standard method, i.e. direct spirometry to analyse maximal oxygen uptake (generic means to measure the $\mathrm{VO}_{2 \max }$ ) [31-34]. However, those studies measured $\mathrm{VO}_{2 \max }$ during treadmill tests, a condition that does not occur during matches. The remaining studies (six in total) utilized indirect methods to predict the athletes' $\mathrm{VO}_{2 \max }[1,16,35-38]$. Additionally, no studies have been found that investigated the aerobic profile of female athletes in Brazilian jiu-jitsu. Brazilian jiu-jitsu is a combat sport, characterized by intermittency, due to the performance of high-intensity efforts interspersed with rest periods [39]. During the match, fluctuations are observed in effort intensity; however, this intensity is very difficult to measure, as the actions performed during the match depend on technical and tactical movements, the opponents and the fighting style $[3,40]$. Indeed, the aerobic contribution is predominant in other combat sports, such as karate [41, 42], taekwondo [43, 44] and boxing [45]. Nevertheless, no studies have been found that investigated aerobic fitness during Brazilian jiu-jitsu matches. The measurement of the energy system's contribution during a Brazilian jiujitsu match seems to present a challenge for sport science researchers. This is because it is difficult to assess the specific pathways in the fight demand, given that the fight involves guard passing techniques, sweeps, takedowns, back control, submissions, and direct contact with the ground and the opponent [39]. The development of specific tests would be important to estimate the physiological demand of Brazilian jiu-jitsu matches, as tests for guarder and passer athletes could help coaches to adjust their training prescriptions.

Maximal efforts performed with a duration of more than $75 \mathrm{~s}$ show the predominance of the aerobic contribution [46], and high-intensity interval training has been shown to be a good method for improving aerobic and anaerobic fitness for the general population, as well as for athletes from several sports modalities [47]. In combat sports, few studies have investigated high-intensity interval training [36, 47-51]. Only Ribeiro et al. [36] used specific actions/movements of Brazilian jiu-jitsu; the other studies employed generic means, such as running, for improving aerobic and anaerobic fitness. However, the study by Ribeiro et al. [52] has some limitations, such as the use of indirect tests to estimate $\mathrm{VO}_{2 \max }$ and a lack of statistical comparisons between groups. They only used the effect size to verify that high-intensity interval training was better than the usual Brazilian jiu-jitsu training.

An analysis of the table (Table 3) shows that aerobic fitness is not able to discriminate the performance of Brazilian jiu-jitsu athletes of different competitive levels (in accordance with the statistical analysis). These results are in line with other combat sports, such as judo [10]. However, the development of aerobic fitness can be relevant to the recovery between/ during matches [10]. This would be important because Brazilian jiu-jitsu athletes perform several matches during one day of competition [2]. Finally, it would be interesting to carry out tests to estimate $\mathrm{VO}_{2 \max }$ on a cycle ergometer for upper and lower limbs as these responses could help coaches in the prescription of generic and specific training.

\section{Anaerobic Profile}

This topic is not a review of the glycolytic anaerobic system. However, to enable better understanding, it was decided to include some information concerning this system, to provide a greater insight into the energetic demand of Brazilian jiu-jitsu matches. Anaerobic capacity and anaerobic power are widely involved in different combat sports because the decisive moments in these sports involve great energy demands, which cannot be supplied solely by oxidative metabolism [10]. The Wingate test has often been used to estimate anaerobic performance in the combat sports domain, such as for judo and wrestling [10, 53]. Although the Wingate test is a generic test and cannot be classified as a gold-standard measure, the test presents a large sensibility in the different phases of sports training periodization [53]. Furthermore, the maintenance of high-intensity efforts is associated with anaerobic power and capacity, i.e. power refers to the peak, while capacity refers to the average during $30 \mathrm{~s}$ of the Wingate test [10]. 
Table 3 Aerobic fitness of Brazilian jiu-jitsu athletes (data are presented as the mean \pm SD)

\begin{tabular}{|c|c|c|c|}
\hline Athlete characteristics $(n)$ & Test & $\mathrm{VO}_{2 \max }(\mathrm{ml} / \mathrm{kg} / \mathrm{min})$ & References \\
\hline State level athletes $(n=5)$ & Graded exercise test in treadmill (direct) & $45.2 \pm 2.4$ & Leitão da Silva [31] \\
\hline Athletes of different competitive levels $(n=9)$ & $1600 \mathrm{~m}$ test & $50.4 \pm 4.0$ & Mazzoccante et al. [35] ${ }^{\mathrm{a}}$ \\
\hline State level athletes—white to purple belt $(n=9)$ & $2400 \mathrm{~m}$ test & $42.4 \pm 5.6$ & Ribeiro et al. [36] \\
\hline State level athletes - white to purple belt $(n=9)$ & & $46.3 \pm 7.0$ & \\
\hline State level athletes $(n=9)$ & & $46.3 \pm 7.0$ & \\
\hline Practitioners $(n=136)$ & Queens College step & $52.2 \pm 7.9$ & Schwartz et al. [16] \\
\hline Athletes of different competitive levels $(n=10)$ & $1600 \mathrm{~m}$ test & $50.2 \pm 4.3$ & Mazzoccante et al. [37] ${ }^{\mathrm{b}}$ \\
\hline State level athletes_-purple to black belt $(n=14)$ & $1600 \mathrm{~m}$ test & $49.0 \pm 3.2$ & Silva et al. [38] \\
\hline State level athletes — white belt $(n=14)$ & & $51.0 \pm 3.6$ & \\
\hline High level athletes $(n=7)$ & Graded exercise test in treadmill (direct) & $42.7 \pm 3.2$ & Rezende et al. [32] \\
\hline State level athletes $(n=8)$ & Graded exercise test in treadmill (direct) & $49.8 \pm 2.3$ & Borges et al. [33] ${ }^{c}$ \\
\hline \multirow[t]{2}{*}{ Practitioners $(n=30)$} & Graded exercise test in treadmill (direct) & $52.0 \pm 6.9$ & Mazzocante et al. [34] \\
\hline & $1600 \mathrm{~m}$ test & $52.1 \pm 5.1$ & \\
\hline High level athletes $(n=10)$ & Graded exercise test in treadmill (indirect) & $49.4 \pm 3.6$ & Vidal-Andreato et al. [1] \\
\hline
\end{tabular}

$\mathrm{VO}_{2 \text { max: }}$ aerobic power

Direct method: using gas analyser

Indirect method: means by validated formulas

${ }^{\mathrm{a}} 12.4 \pm 1.3 \mathrm{~km} / \mathrm{h}$ for the anaerobic threshold velocity

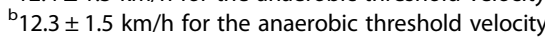

${ }^{c} 41.7 \pm 2.0 \mathrm{ml} / \mathrm{kg} / \mathrm{min}$ at anaerobic threshold

Del Vecchio et al. [3] performed a Wingate test for lower limbs on Brazilian jiu-jitsu high-level athletes $(n=7)$, with $7.5 \%$ of the body mass of the athletes, and observed the following values for the variables analysed: peak power $(10.1 \pm 1.2 \mathrm{~W} / \mathrm{kg})$, mean power $(9.9 \pm 1.4 \mathrm{~W} / \mathrm{kg})$ and fatigue index $(48.2 \pm 9.4 \%)$, respectively. In another study, Leitão da Silva [31] reported the following values for the Wingate test on lower limbs in Brazilian jiu-jitsu athletes $(n=5)$, also using $7.5 \%$ of the body mass: peak power $(11.5 \pm 1.4 \mathrm{~W} / \mathrm{kg})$, mean power $(9.8 \pm 0.4 \mathrm{~W} / \mathrm{kg})$ and fatigue index $(56.5 \pm 11.0 \%)$, respectively.

In fact, anaerobic power and anaerobic capacity represent the ability to generate and maintain a high-intensity performance over seconds that can be extended up to a few minutes [54]. Moreover, anaerobic capacity and anaerobic power are associated with maintaining an intermittent performance of high intensity, in which the decisive sports actions are dependent on movement and powerful actions $[55,56]$. The values obtained for peak power and mean power from Brazilian jiu-jitsu athletes are higher than those considered excellent for healthy people [53]. However, the elaboration of an anaerobic profile of Brazilian jiu-jitsu athletes is limited by low number of studies. Only two studies reporting the anaerobic responses in the Wingate test for lower limbs were found, and the anaerobic responses in the Wingate test to upper limbs are still unknown.

Based on the aspects listed above, the lack of studies that have investigated the anaerobic responses in lower limbs and the absence of studies focusing on upper limbs are noteworthy. Nevertheless, recently a specific jiu-jitsu anaerobic performance test was proposed that required performance in an adapted protocol (i.e. Brazilian jiu-jitsu technique). The authors found a correlation between high lactate concentrations and heart rate values measured during simulated Brazilian jiu-jitsu combat and the specific jiu-jitsu anaerobic performance test [57]. Thus, the realization of adapted protocols for the measurement of high-intensity intermittent performance (for example: four sets $\times 1$ min execution with $45 \mathrm{~s}$ recovery time) can assist coaches in their training prescriptions aimed at maintaining high-intensity intermittent performance [57].

\section{Maximum Isometric Handgrip Strength}

Maximum isometric strength is characterized by actions that do not alter the muscle length, i.e. there is no movement of the joint, and thus, it is static $[58,59]$. In grappling combat sports, such as Brazilian jiu-jitsu, judo and wrestling, there is a great demand for maximal isometric handgrip strength [60]. For elite or experienced Brazilian jiu-jitsu athletes, the different studies showed maximum isometric handgrip strength values of between 48 and 57 $\mathrm{kg}$ force (kgf) (Table 4). Grip endurance seems to be an important factor for success in immobilizations, takedowns, throws and submissions. It is worth highlighting as a possible limitation that these adjustments generated by isometric training are angle-dependent; thus, the adaptations occur at the angles in which the stimuli occur 
Table 4 Isometric handgrip strength (IHGS) of Brazilian jiu-jitsu athletes (data are presented as the mean \pm SD)

\begin{tabular}{|c|c|c|c|}
\hline Athlete characteristics $(n)$ & $\begin{array}{l}\text { Right IHGS } \\
\text { (kgf) }\end{array}$ & $\begin{array}{l}\text { Left IHGS } \\
\text { (kgf) }\end{array}$ & References \\
\hline \multicolumn{4}{|l|}{ Male } \\
\hline High level athletes $(n=14)$ & $53.5 \pm 3.2^{a}$ & $48.5 \pm 5.2^{b}$ & Diaz-Lara et al. [106] \\
\hline State level athletes_-brown and black belt $(n=10)$ & $53 \pm 6^{\mathrm{a}}$ & $50 \pm 9^{b}$ & Andreato et al. [4] \\
\hline High level athletes $(n=26)$ & $48.5 \pm 5.6^{\mathrm{a}}$ & $50.8 \pm 5.2^{b}$ & Diaz-Lara et al. [89] \\
\hline State level athletes $(n=22)$ & $54.2 \pm 6.7^{c}$ & $51.4 \pm 6.1$ & Franchini et al. [72] \\
\hline State level athletes_-blue to black belt $(n=15)$ & $48.1 \pm 5.7$ & $45.5 \pm 7.9$ & Follmer et al. [90] \\
\hline State level athletes $^{d}$ & & & Gasparotto et al. [107] \\
\hline White belt $(n=18)$ & $40.1 \pm 2.5^{\mathrm{e}}$ & & \\
\hline Blue belt $(n=15)$ & $46.3 \pm 3.3^{e}$ & & \\
\hline Purple belt $(n=20)$ & $41.4 \pm 3.5^{\mathrm{e}}$ & & \\
\hline Practitioners $(n=136)$ & $103 \pm 17^{f}$ & & Schwartz et al. [16] \\
\hline State level athletes_blue belt $(n=12)$ & $38.0 \pm 6.3^{\mathrm{a}}$ & $32.3 \pm 6.3^{b}$ & Andreato et al. [108] \\
\hline High level athletes & & & Diaz-Lara et al. [20] \\
\hline Novice—white to blue belt $(n=24)$ & $43.6 \pm 7.1^{9}$ & $43.3 \pm 6.6^{9}$ & \\
\hline Expert—purple to black belt $(n=32)$ & $48.6 \pm 6.1$ & $49.1 \pm 7.0$ & \\
\hline High level athletes $(n=49)$ & $47.8 \pm 8.3$ & $46.2 \pm 7.6$ & Pietraszewska et al. [94] \\
\hline Experienced-purple to black $(n=14)$ & $52.4 \pm 11.8$ & $50.6 \pm 11.6$ & Silva et al. [38] \\
\hline Beginners—white belt $(n=14)$ & $46.7 \pm 6.5$ & $47.2 \pm 5.8$ & \\
\hline State level athletes-white to brown belt $(n=35)$ & $45.9 \pm 10.3$ & $44.2 \pm 11.1$ & Andreato et al. [40] \\
\hline State level athletes & & & Costa and Oliveira [109] \\
\hline White and blue belt $(n=29)$ & $43.6 \pm 9.0$ & $41.1 \pm 7.2$ & \\
\hline Purple to black belt $(n=17)$ & $46.3 \pm 8.9$ & $45.1 \pm 9.6$ & \\
\hline All $(n=46)$ & $43.8 \pm 10.2$ & $42.3 \pm 9.6$ & \\
\hline Beginner athletes—white and blue belt $(n=7)$ & $52.5 \pm 9.1$ & $49.9 \pm 7.2$ & Coswig et al. [21] \\
\hline Experienced athletes-more than purple belt and high level $(n=7)$ & $57.0 \pm 8.4$ & $55.6 \pm 7.6$ & \\
\hline High level $(n=11)$ & $43.7 \pm 4.8$ & $40.1 \pm 3.8$ & Vidal-Andreato et al. [1] \\
\hline State level athletes-white and blue belt $(n=5)$ & $33.6 \pm 5.5^{a}$ & & Neto and Dechechi, [110] \\
\hline High level athletes $^{d}$ & & & Matuzaki et al. [69] \\
\hline White belt $(n=15)$ & $42.3 \pm 10.2^{e}$ & & \\
\hline Blue belt $(n=17)$ & $49.2 \pm 11.3^{e}$ & & \\
\hline Black belt $(n=6)$ & $50.2 \pm 5.2^{e}$ & & \\
\hline High level athletes_-brown and black belt $(n=21)$ & $51.2 \pm 10.7$ & $48.2 \pm 10.3$ & Oliveira et al. [62] \\
\hline High level athletes_-blue and purple belt $(n=29)$ & $49.6 \pm 8.2$ & $46.2 \pm 8.2$ & \\
\hline All $(n=50)$ & $50.3 \pm 9.1$ & $47.0 \pm 9.0$ & \\
\hline
\end{tabular}

Kgf kilogramme force

${ }^{a}$ Dominant handgrip

${ }^{\mathrm{b}}$ Non-dominant handgrip

'Significant difference versus left handgrip from the same study

${ }^{\mathrm{d}}$ There was no comparison between groups

eDid not report the side evaluated

fSum of both hands

${ }^{9}$ Significant difference versus expert group from the same study

[59]. One study shows differences between maximum isometric handgrip strength of the right and left hands, in which the right hand had higher values than the left hand in Brazilian jiu-jitsu athletes [61].

\section{Dynamic Strength}

The data available in the scientific literature are limited to maximum dynamic strength in Brazilian jiu-jitsu athletes, and a few studies have investigated these responses 
in these athletes; furthermore, there are no data available in the scientific literature for maximum strength in female Brazilian jiu-jitsu athletes. Thus, more research needs to be conducted on this topic. One-repetition-maximum (1RM) tests have been widely used for strength training prescription [62]. Maximal dynamic strength can be associated with sporting excellence or success in Brazilian jiu-jitsu athletes because studies have shown that 1RM performance for the bench press was greater in advanced or elite than in non-advanced or non-elite athletes $[25,31]$ (Table 5). In Olympic wrestlers, these same differences between different level groups are also observed for the bench press exercise and are also found in lower limbs (e.g. squat exercise) [63].

Moreover, strength training plays an important role in training periodization, because it serves as the basis for

Table 5 One-repetition-maximum (1RM) data in different exercises performed by Brazilian jiu-jitsu athletes (data are presented as the mean \pm SD)

\begin{tabular}{|c|c|c|c|c|}
\hline Athlete characteristics $(n)$ & Strength test & Absolute 1RM score $(\mathrm{kg})$ & Relative 1RM score (kg/body mass) & References \\
\hline \multicolumn{5}{|l|}{ Male } \\
\hline High level athletes $(n=8)$ & Bench press & $111 \pm 6^{a}$ & $1.46 \pm 0.13$ & Marinho et al. [25] \\
\hline State level athletes $(n=10)$ & & $98 \pm 6$ & $1.36 \pm 0.11$ & \\
\hline High level athletes $(n=14)$ & & $90.5 \pm 7.7$ & $1.27 \pm 0.27$ & Diaz-Lara et al. [106] \\
\hline $\begin{array}{l}\text { High level athletes_-brown and black } \\
\text { belt }^{\mathrm{b}}\end{array}$ & & $115 \pm 16^{c}$ & $1.48 \pm 0.15^{c}$ & Leitão da Silva et al. [31] \\
\hline $\begin{array}{l}\text { Intermediary athletes_-blue belt and } \\
\text { purple }^{\text {b }}\end{array}$ & & $101 \pm 13$ & $1.32 \pm 0.14$ & \\
\hline $\begin{array}{l}\text { High level athletes_blue to black } \\
\text { belt }(n=23)\end{array}$ & & $103.4 \pm 22.9$ & $1.3 \pm 0.2$ & Silva et al. [111] \\
\hline State level athletes $(n=20)$ & & $85.8 \pm 17.8$ & $N R$ & Costa et al. [112] \\
\hline $\begin{array}{l}\text { State level athletes_purple to black } \\
\text { belt }(n=5)\end{array}$ & & $94 \pm 24$ & NR & Rigatto [103] \\
\hline $\begin{array}{l}\text { State level athletes-purple to black } \\
\text { belt }(n=7)\end{array}$ & & $87 \pm 31$ & $N R$ & \\
\hline High level athletes $(n=7)$ & & $109 \pm 18$ & $1.39 \pm 0.26$ & Del Vecchio et al. [3] \\
\hline High level athletes $(n=8)$ & Squat & $91 \pm 8$ & $1.20 \pm 0.13$ & Marinho et al. [25] \\
\hline State level athletes $(n=10)$ & & $88 \pm 7$ & $1.23 \pm 0.13$ & \\
\hline High level athletes $(n=7)$ & & $110 \pm 15$ & $1.38 \pm 0.19$ & Del Vecchio et al. [3] \\
\hline $\begin{array}{l}\text { State level athletes_-purple to black } \\
\text { belt }(n=5)\end{array}$ & Lat pull-down & $90 \pm 18$ & NR & Rigatto [103] \\
\hline $\begin{array}{l}\text { State level athletes_-purple to black } \\
\text { belt }(n=7)\end{array}$ & & $86 \pm 15$ & $N R$ & \\
\hline $\begin{array}{l}\text { State level athletes-purple to black } \\
\text { belt }(n=5)\end{array}$ & Military press & $56 \pm 17$ & $N R$ & Rigatto [103] \\
\hline $\begin{array}{l}\text { State level athletes_-purple to black } \\
\text { belt }(n=7)\end{array}$ & & $57 \pm 22$ & $N R$ & \\
\hline High level athletes- $(n=11)$ & Leg Press & $308 \pm 88$ & NR & Fernandes et al. [113] \\
\hline High level athletes $(n=7)$ & Deadlift & $138 \pm 24$ & $1.72 \pm 0.31$ & Del Vecchio et al. [3] \\
\hline $\begin{array}{l}\text { State level athletes-purple to black } \\
\text { belt }(n=5)\end{array}$ & Biceps curl & $91 \pm 25$ & $N R$ & Rigatto [103] \\
\hline $\begin{array}{l}\text { State level athletes_-purple to black } \\
\text { belt }(n=7)\end{array}$ & & $52 \pm 29$ & NR & \\
\hline $\begin{array}{l}\text { State level athletes_purple to black } \\
\text { belt }(n=5)\end{array}$ & $\begin{array}{l}\text { Elbow extension in } \\
\text { the pulley }\end{array}$ & $114 \pm 28$ & NR & Rigatto [103] \\
\hline $\begin{array}{l}\text { State level athletes_purple to black } \\
\text { belt }(n=7)\end{array}$ & & $64 \pm 41$ & NR & \\
\hline
\end{tabular}


the other periodization phases, such as strength endurance and muscle power (Table 6) [64]. It is worth mentioning that strength training must emphasize the main muscles related to the movements and actions performed during the matches. Hypertrophy training may be harmful to the athlete who is weighing in near the upper limit of their category because the hypertrophy will provide weight gain [65]. In addition, maximum strength training can be an important tool for athletes, since there will be an increase in this capacity and not muscular hypertrophy [66]. In this regard, the specific literature gives to sport scientists and coaches some interesting values in relation to relative 1RM score both for upper and lower limbs in Brazilian jiu-jitsu elite athletes (i.e. bench press $1.3-1.5 \mathrm{~kg} / \mathrm{body}$ mass, squat $1.2 \mathrm{~kg} /$ body mass and deadlift $1.7 \mathrm{~kg} /$ body mass) (Table 4). Knowledge of these results is important for drawing comparisons.

Similarly, a few studies have described the maximum torque in Brazilian jiu-jitsu athletes. This test (isokinetic) has been used extensively to measure muscle imbalances between the different sides of the body and the

Table 6 Peak torque $\left(\mathrm{N} \mathrm{m} \mathrm{kg}{ }^{-1}\right)$, power $(\mathrm{W})$ or total work $(\mathrm{J})$ during isokinetic maximal tests performed by Brazilian jiu-jitsu athletes (data are presented as the mean \pm SD)

\begin{tabular}{|c|c|c|c|}
\hline Athlete characteristics ( $n$ ) & Exercise & Result & References \\
\hline \multicolumn{4}{|l|}{ Male } \\
\hline \multirow{12}{*}{$\begin{array}{l}\text { State level athletes- } \\
\text { blue to black belt } \\
(n=15)\end{array}$} & Elbow flexion & & $\begin{array}{l}\text { Follmer } \\
\text { et al. [90] }\end{array}$ \\
\hline & $\mathrm{PT}_{45^{\circ}}\left(\mathrm{N} \mathrm{m} \mathrm{kg}{ }^{-1}\right)$ & $0.77 \pm 0.12$ & \\
\hline & $\mathrm{PT}_{90^{\circ}}\left(\mathrm{N} \mathrm{m} \mathrm{kg}{ }^{-1}\right)$ & $0.91 \pm 0.16$ & \\
\hline & $\mathrm{PT}_{120^{\circ}}\left(\mathrm{N} \mathrm{m} \mathrm{kg}^{-1}\right)$ & $0.77 \pm 0.13$ & \\
\hline & $\mathrm{PT}_{\mathrm{CON}}\left(\mathrm{N} \mathrm{m} \mathrm{kg}{ }^{-1}\right)$ & $0.68 \pm 0.17$ & \\
\hline & $\mathrm{PT}_{\mathrm{ECC}}\left(\mathrm{N} \mathrm{m} \mathrm{kg}^{-1}\right)$ & $0.87 \pm 0.20$ & \\
\hline & Elbow extension & & \\
\hline & $\mathrm{PT}_{45^{\circ}}\left(\mathrm{N} \mathrm{m} \mathrm{kg}^{-1}\right)$ & $0.63 \pm 0.10$ & \\
\hline & $\mathrm{PT}_{90^{\circ}}\left(\mathrm{N} \mathrm{m} \mathrm{kg}{ }^{-1}\right)$ & $0.71 \pm 0.13$ & \\
\hline & $\mathrm{PT}_{120^{\circ}}\left(\mathrm{N} \mathrm{m} \mathrm{kg}^{-1}\right)$ & $0.71 \pm 0.13$ & \\
\hline & $\mathrm{PT}_{\mathrm{CON}}\left(\mathrm{N} \mathrm{m} \mathrm{kg}{ }^{-1}\right)$ & $0.79 \pm 0.19$ & \\
\hline & $\mathrm{PT}_{\mathrm{ECC}}\left(\mathrm{N} \mathrm{m} \mathrm{kg}{ }^{-1}\right)$ & $1.10 \pm 0.25$ & \\
\hline \multirow[t]{8}{*}{$\begin{array}{l}\text { State level athletes } \\
(n=15)\end{array}$} & Knee flexion & & $\begin{array}{l}\text { Assis et al. } \\
{[115]}\end{array}$ \\
\hline & PT $(\mathrm{N} / \mathrm{m})$ & $187^{\mathrm{a}}$ & \\
\hline & Power (W) & 252 & \\
\hline & Total work (J) & 1913 & \\
\hline & Knee extension & & \\
\hline & PT (N/m) & $308^{\mathrm{a}}$ & \\
\hline & Power (W) & $286^{\mathrm{a}}$ & \\
\hline & Total work (J) & 1614 & \\
\hline
\end{tabular}

$P T$ peak torque, $P T_{\text {CON }}$ peak torque concentric, $P T_{E C C}$ peak torque eccentric

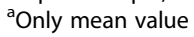

antagonistic muscles. Usually, this test is indicated after surgery and injuries during rehabilitation; moreover, values equal to or less than $5 \%$ for the different limbs are considered ideal after rehabilitation for returning to sports training [67].

\section{Muscle Power}

Several authors explain that the decisive moments that determine the result of a match (guard passes, sweeps, takedowns etc.) require muscular power actions [34, 68, 69]. Jump performance can be a factor that discriminates between two groups with different levels of training and experience in Brazilian jiu-jitsu [20]. Recent studies have found that Brazilian jiu-jitsu athletes scored high results in the CMJ, which ranged between 30 and $45 \mathrm{~cm}$ (Table 7), which was higher than data from Olympic wrestlers [70] and similar to that from senior top elite judo athletes [71]. The vertical jump height showed no gradual decrease during the simulated competition (i.e. four matches of $10 \mathrm{~min}$ ) [4].

However, when the bench press throwing exercise was used to determine peak power, no difference was found with loads of $1 \mathrm{RM}$ between 30 and $60 \%$ between advanced and non-advanced Brazilian jiu-jitsu competitors [68]. Lastly, there are two research studies that analysed the load that optimized muscle power output in Brazilian jiu-jitsu [68] in the bench press throw exercise $(\sim 42 \%$ of $1 \mathrm{RM})$ and [72] in the bench press $(45.1 \pm 12.9 \%$ of $1 R M)$. Slightly lower results in the bench press exercise were observed for wrestlers, who obtained their maximal power production at $34-37 \%$ of $1 \mathrm{RM}$.

Based on the results specified above, it can be concluded that decisive actions and therefore athletic performance during Brazilian jiu-jitsu matches are mainly dependent on muscular power, both in upper and lower limbs.

\section{Muscular Endurance}

Muscular endurance is the ability of a muscle or a group of muscles to sustain repeated contractions against resistance for an extended period [73]. The Brazilian jiu-jitsu athlete during a match is in contact with the opponent most of the time and must maintain a strong grip on different body parts [69]. Thus, due to this dynamic, the most gripping actions performed in Brazilian jiu-jitsu require high resistance to maintain constant levels of strength endurance for a long time. In addition, there is a consensus in the specific literature on the importance of grip strength endurance or gripping endurance $[1,34,74]$. Corroborating this assertion, Andreato et al. [4] revealed that Brazilian jiu-jitsu athletes in competitive situations reported higher perceptions of fatigue in the forearm region (68\%). Thus, the training of this region should be covered in the training programme. 
Table 7 Muscle power in Brazilian jiu-jitsu athletes (data are presented as the mean \pm SD)

\begin{tabular}{|c|c|c|c|}
\hline Athlete characteristics ( $n$ ) & Exercise & Result (cm) & References \\
\hline \multicolumn{4}{|l|}{ Male } \\
\hline State level athletes $(n=10)$ & Throw the medicine ball & $428 \pm 33$ & Nascimento [73] \\
\hline State level athletes-white and blue belt $(n=5)$ & & $380 \pm 48$ & Neto and Dechechi [110] \\
\hline High level athletes $(n=14)$ & Countermovement jump & $40.6 \pm 2.6$ & Diaz-Lara et al. [106] \\
\hline State level athletes_-brown and black belt $(n=10)$ & & $41 \pm 6$ & Andreato et al. [4] \\
\hline High level athletes $(n=26)$ & & $34.0 \pm 5.2$ & Diaz-Lara et al. [89] \\
\hline State level athletes & & & Diaz-Lara et al. [20] \\
\hline Novice- white to blue belt $(n=24)$ & & $29.7 \pm 5.0^{\mathrm{a}}$ & \\
\hline Expert—purple to black belt $(n=32)$ & & $34.2 \pm 5.1$ & \\
\hline State level athletes_-blue to black belt $(n=23)$ & & $40.8 \pm 5.5$ & Silva et al. [111] \\
\hline State level athletes - blue to purple belt $(n=22)$ & & $45.5 \pm 1.3$ & Detanico et al. [114] \\
\hline State level athletes $(n=9)^{\mathrm{b}}$ & Vertical Jump & $39.9 \pm 8.1$ & Ribeiro et al. [36] \\
\hline State level athletes $(n=9)^{\mathrm{b}}$ & & $48.3 \pm 5.9$ & \\
\hline High level athletes $(n=49)$ & Standing long jump & $234 \pm 22$ & Pietraszewska et al. [94] \\
\hline Beginner athletes-white and blue belt $(n=7)$ & & $225 \pm 25$ & Coswig et al. [21] \\
\hline Experienced athletes - more than purple belt and national level $(n=7)$ & & $226 \pm 12$ & \\
\hline State level athletes $(n=10)$ & & $237 \pm 23$ & Nascimento [73] \\
\hline State level athletes-white and blue belt $(n=5)$ & Standing long jump & $234 \pm 25$ & Neto and Dechechi, [110] \\
\hline
\end{tabular}

${ }^{\mathrm{a} S i g n i f i c a n t}$ difference versus expert group from the same study

${ }^{\mathrm{b}}$ The study included two different groups with athletes with the same characteristics

There are two specific tests that evaluate gripping endurance, one statically: maximum static lift (grip endurance with gi or kimono) and one dynamically: maximum dynamic lift (chin-up repetitions with gi or kimono) [75-78]. Mean grip endurance performances reported for national and international competitors in the literature ranged from 54 to $62 \mathrm{~s}$ (Table 8). These grip endurance performances are higher than those generated by elite judo athletes at $35 \pm 18 \mathrm{~s}$ [75], whereas the repetitions with kimono performances ranged between 15 and 18 reps (Table 8), which was also slightly higher than elite judo athletes at $12 \pm 5$ reps [76]. However, Franchini et al. [77] indicated that state-level athletes had similar values to elite athletes in judogi chin-up repetitions (isometric and dynamic endurance strength). Therefore, the development of studies that elaborate normative tables with a large sample size may be relevant for classifying Brazilian jiu-jitsu athletes.

Both tests can discriminate among athletes with different levels and experience in Brazilian jiu-jitsu [38, 75, 78]. However, the permanence of static isometric grip strength could be a completely specific and individualized manifestation for Brazilian jiu-jitsu due to the major permanence of grip holding during Brazilian jiu-jitsu matches versus other grappling sports [3].

It is common in combat sports to evaluate muscular endurance using sit-ups and push-ups. Brazilian jiu-jitsu elite athletes were rated as excellent for abdominal and upper limb strength endurance [1]. The results in sit-ups (Table 7) are similar to those for elite junior judo athletes [79] and international medallists in taekwondo [13]. In the push-ups test, lower results are observed compared to other similar elite athletes both in judo [80] and wrestling [80]. From all the results presented above, it is possible to conclude that muscle endurance is one of the most critical components of Brazilian jiu-jitsu performance, for many reasons: athletes need to have high abdominal strength endurance and maintain a strong grip for an extended amount of time [1, 2, 4, 69], and additionally, they must repeat muscular power actions during the development of combat or as match duration increases [60].

\section{Flexibility}

Flexibility is a relevant physical component of Brazilian jiu-jitsu, specifically in the thoracolumbar spine and hamstrings, which are required to perform specific situations of attack or defence $[1,7]$. A high level of flexibility can help Brazilian jiu-jitsu athletes to perform positions. In addition, good flexibility can facilitate the learning of these motor gestures [1]. However, there are no specific tests for evaluating the flexibility of Brazilian jiu-jitsu athletes, and therefore, it is necessary to develop tests for such purposes. Table 9 shows the results on the flexibility of Brazilian jiu-jitsu athletes in the sit-and-reach test. 
Table 8 Muscular endurance in different exercises performed by Brazilian jiu-jitsu athletes (data are presented as the mean \pm SD)

\begin{tabular}{|c|c|c|c|}
\hline Athlete characteristics $(n)$ & Exercise & Result (s or rep.) & References \\
\hline \multicolumn{4}{|l|}{ Male } \\
\hline High level athletes $(n=14)$ & Grip endurance with gi & $54.4 \pm 13.4 \mathrm{~s}$ & Diaz-Lara et al. [106] \\
\hline Athletes_brown and black belt $(n=8)$ & & $28 \pm 9 s$ & Andreato et al. [4] \\
\hline Athletes-blue to black belt $(n=15)$ & & $41 \pm 16 s$ & Follmer et al. [90] \\
\hline High level athletes $(n=49)$ & & $40 \pm 11 \mathrm{~s}$ & Pietraszewska et al. [94] \\
\hline High level athletes $(n=10)$ & & $61 \pm 19 s$ & Pinho-Júnior et al. [96] \\
\hline Experienced-purple to black $(n=14)$ & & $45 \pm 10 s^{a}$ & Silva et al. [38] \\
\hline Beginners—white belt $(n=14)$ & & $36 \pm 10 s$ & \\
\hline Athletes of different competitive levels $(n=10)$ & & $62 \pm 14 s^{b, c}$ & Silva et al. [78] \\
\hline Athletes of different competitive levels $(n=10)$ & & $60 \pm 0 s^{b, c}$ & \\
\hline Practitioners $(n=10)$ & & $43 \pm 5 s^{c}$ & \\
\hline Beginners-white belt $(n=10)$ & & $28 \pm 9 s$ & \\
\hline High level athletes $(n=9)$ & & $63 \pm 19 s$ & Santos et al. [100] \\
\hline High level athletes $(n=10)$ & & $56 \pm 11 s^{d}$ & Silva et al. [75] \\
\hline State level athletes $(n=10)$ & & $38 \pm 11 \mathrm{~s}$ & \\
\hline Athletes—blue to black belt $(n=15)$ & Repetitions with gi & $10 \pm 5$ rep & Follmer et al. [90] \\
\hline High level athletes $(n=10)$ & & $15 \pm 2$ rep & Pinho-Júnior et al. [96] \\
\hline Experienced-purple to black $(n=14)$ & & $10 \pm 3$ rep & Silva et al. [38] \\
\hline Beginners-white belt $(n=14)$ & & $8 \pm 3$ rep & \\
\hline High level athletes $(n=10)$ & & $18 \pm 3$ rep $^{\mathrm{b}, \mathrm{c}}$ & Silva et al. [78] \\
\hline State level athletes $(n=10)$ & & $17 \pm 3$ rep $^{\mathrm{b}, \mathrm{c}}$ & \\
\hline Practitioners $(n=10)$ & & $9 \pm 3$ rep & \\
\hline Beginners-white belt $(n=10)$ & & $7 \pm 3$ rep & \\
\hline High level athletes $(n=9)$ & & $15 \pm 2$ rep & Santos et al. [100] \\
\hline High level athletes $(n=10)$ & & $15 \pm 4$ rep $^{d}$ & Silva et al. [75] \\
\hline State level athletes $(n=10)$ & & $8 \pm 3$ rep & \\
\hline Beginner athletes - white and blue belt $(n=7)$ & & $10 \pm 3$ rep & Coswig et al. [21] \\
\hline Experienced athletes-more than purple belt and national level $(n=7)$ & & $15 \pm 2$ rep & \\
\hline High level athletes $(n=14)$ & Bench press at $45 \% 1 \mathrm{RM}$ & $22 \pm 8$ rep & Diaz Lara et al. [106] \\
\hline High level athletes $(n=8)$ & Push-ups & $41 \pm 3$ rep $^{f}$ & Marinho et al. [25] \\
\hline State level athletes $(n=10)$ & & $36 \pm 3$ rep & \\
\hline High level athletes $(n=11)$ & & $39 \pm 8$ rep & Vidal-Andreato et al. [1] \\
\hline High level athletes $(n=8)$ & Sit-ups & $46 \pm 4$ rep $^{f}$ & Marinho et al. [25] \\
\hline State level athletes $(n=10)$ & & $40 \pm 3$ rep & \\
\hline State level athletes $(n=9)$ & & $52 \pm 19$ rep & Ribeiro et al. [36] \\
\hline State level athletes $(n=9)$ & & $68 \pm 11$ rep & \\
\hline Practitioners $(n=136)$ & & $62 \pm 16$ rep & Schwartz et al. [16] \\
\hline High level athletes $(n=49)$ & & $35 \pm 5$ rep & Pietraszewska et al. [94] \\
\hline High level athletes $(n=11)$ & & $52 \pm 7$ rep & Vidal-Andreato et al. [1] \\
\hline
\end{tabular}

${ }^{\mathrm{a} S i g n i f i c a n t ~ d i f f e r e n c e ~ v e r s u s ~ b e g i n n e r s ~ g r o u p ~ f r o m ~ t h e ~ s a m e ~ s t u d y ~}$ bignificant difference versus recreational group from the same study

'Significant difference versus beginners group from the same study

${ }^{\mathrm{d}}$ Significant difference versus non-elite group from the same study

eSignificant difference versus experienced group from the same study

${ }^{f}$ Significant difference versus non-elite group from the same study 
Table 9 Flexibility of Brazilian jiu-jitsu athletes as measured by the sit-and-reach test (data are presented as mean \pm SD)

\begin{tabular}{|c|c|c|}
\hline Athlete characteristics $(n)$ & Sit-and-reach $(\mathrm{cm})$ & Reference \\
\hline \multicolumn{3}{|l|}{ Male } \\
\hline High level athletes $(n=8)$ & $40 \pm 3^{a}$ & Marinho et al. [25] \\
\hline State level athletes $(n=10)$ & $32 \pm 3$ & \\
\hline Athletes-brown and black belt $(n=10)$ & $26 \pm 8$ & Andreato et al. [4] \\
\hline Practitioners $(n=136)$ & $27 \pm 9$ & Schwartz et al. [16] \\
\hline Athletes-adult $(n=30)$ & $22 \pm 8$ & Araujo et al. [81] \\
\hline Athletes-master $(n=7)$ & $26 \pm 7$ & \\
\hline Athletes_-senior $(n=4)$ & $22 \pm 6$ & \\
\hline Beginner athletes—white and blue belt $(n=7)$ & $28 \pm 2^{b}$ & Coswig et al. [21] \\
\hline Experienced athletes - more than purple belt and national level $(n=7)$ & $35 \pm 4$ & \\
\hline High level athletes $(n=11)$ & $35 \pm 8$ & Vidal-Andreato et al. [1] \\
\hline State level athletes $(n=20)$ & $34 \pm 7$ & \\
\hline High level athletes $(n=7)$ & $43 \pm 3$ & Del Vecchio et al. [3] \\
\hline
\end{tabular}

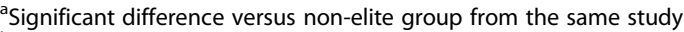

${ }^{\mathrm{b}}$ Significant difference versus experienced group from the same study

For flexibility, evaluated by the sit-and-reach test, there were wide-ranging results, with variations of $22 \mathrm{~cm}$ in adults and senior fighters [81] and up to $43 \mathrm{~cm}$ in highperformance athletes [3]. Thus experience and competitive level seem to influence an athlete's flexibility responses, as experienced athletes had greater flexibility than beginner athletes [21] and elite athletes showed more flexibility than non-elite athletes [25]. Therefore, further studies are needed to confirm the idea that the competitive level can have an influence on flexibility. This idea is plausible, since these results have already been seen in wrestlers, with high-level athletes showing greater flexibility than low-level athletes [11].

\section{Reaction Time}

Success in open skills seems to be determined by the capacity of an individual to adapt his behaviour to changes imposed by their opponent. Often, this adaptation has to be extremely fast [82]. In combat sports, reaction speed is important for athletes to dodge and/or anticipate their opponent's attacks or take advantage of opportune moments for their own attacks [4, 7]. Thus, reaction speed can be crucial in defining matches, in addition to being one of the factors that could explain a drop in performance during a competition. However, despite the importance of this variable, only two studies have evaluated it. In the first study, reaction time (the time it took for the athlete to identify the beep sound; in other words, the first movement in the contact pad) was evaluated, and a value of $239 \pm 17 \mathrm{~ms}$ was found in practitioners of the modality $(n=11)$. Moreover, older individuals (27-35 years old; $n=3 ; 248 \pm 14 \mathrm{~ms}$ ) did not differ from younger individuals (18-26 years old; $n=8 ; 236 \pm 17 \mathrm{~ms}$ )
[83]. In the second study, the response time (the time that athletes take to make a jump after identifying the beep sound) was evaluated and a mean value of $0.40 \pm 0.04 \mathrm{~s}$ was observed in brown and black belt athletes $(n=9)$ [4]. It is important to note that there is a lack of studies evaluating the reaction time in Brazilian jiu-jitsu. Moreover, there are serious limitations in interpreting the results because the test used to evaluate the reaction time is very generic, and the same test is used in different sports.

\section{Conclusions}

In general, Brazilian jiu-jitsu athletes had low body fat, without differences between novices and experts or between elite and non-elite athletes. The mesomorphic component was predominant. Aerobic power was similar to that of other grappling combat sports and did not seem to be influenced by the Brazilian jiu-jitsu athlete's competitive level. Further research is needed to quantify anaerobic power, especially in upper limbs. The values of isometric handgrip strength are not high. However, specific tests for grip strength endurance using the gi can discriminate athletes with different experience and competitive levels in Brazilian jiu-jitsu. More studies are necessary to describe the maximal strength profile of Brazilian jiu-jitsu athletes. However, until now, maximal dynamic strength has been associated with sporting excellence or success in Brazilian jiu-jitsu athletes in upper limbs. Decisive actions and therefore athletic performance during Brazilian jiu-jitsu matches are mainly dependent on muscular power in both upper and lower limbs; however, more studies are necessary to describe the power strength profile of Brazilian jiu-jitsu athletes. With regard to flexibility, experience and competitive level seem to influence an athlete's flexibility responses, as experienced 
athletes had greater flexibility than beginners and elite athletes showed more flexibility than non-elite athletes. Lastly, more research is required to find out whether reaction time can be a determining factor in athletic success in Brazilian jiu-jitsu.

Thus, based on the aspects described above, it is remarkable to note that there are a few studies mapping the performance of Brazilian jiu-jitsu athletes, especially involving variables such as aerobic and anaerobic power and aerobic and anaerobic capacity. Because of the intermittent characteristic of Brazilian jiu-jitsu, it is important to carry out more research to report the anaerobic power and capacity performance of such athletes. Moreover, longitudinal studies describing the responses of Brazilian jiu-jitsu athletes to physical training and competitive performance are incipient. Thus, new studies with this purpose are indispensable. Researches describing the female sex are also indispensable, given that only two studies have investigated this population, in which only body composition was measured. In addition, further research is needed to analyse whether there are differences between sex, belt ranks, competitive level and sport experience time, and among the different weight categories for different variables.

\section{Practical Applications}

There is no doubt that the practice of Brazilian jiu-jitsu has grown exponentially all over the world in the last few decades. As a consequence of this growth, researchers have strived to enhance the quality of investigations on physical and physiological responses to training, combat simulation, competition and official competitions in Brazilian jiu-jitsu. However, there is an urgent need for a better understanding of the referred aspects in order to provide ideal training prescriptions. The available scientific literature on these issues needs to be reinforced, and doubts need to be settled with regard to physical and physiological responses in Brazilian jiu-jitsu.

Additionally, studies seeking to investigate the effects of resistance training for improved performance of flexor and extensor forearm muscles can be relevant for sustaining grip during Brazilian jiu-jitsu matches, given that grip power provides a more effective form of controlling the adversary. Moreover, scientific studies carried out on strength training with different time spans, i.e. linear, undulating, block and complex training, as well as Olympic weightlifting, can be tested on Brazilian jiu-jitsu athletes, with the objective of improving performance in competition. Similarly, there is an urgent need to carry out studies that investigate the effects of protocols that develop flexibility among Brazilian jiu-jitsu athletes, given that many of the "guard fighter" athletes' positions require high flexibility of the torso and lower limbs, thereby facilitating sweeps, back control and the consequent defeat of the opponent.
Finally, it is evident that scientific studies with athletes at international level are scarce, especially among female athletes. As a result of these findings, it is understood that there is an urgent need to carry out comprehensive studies with athletes of different age groups (adults, masters and seniors), different grades (white, blue, purple, brown and black), different weight categories (feather to heavy, as well as absolute), with or without gi (with or without kimono), as well as among male and female athletes. Furthermore, studies that focus on the abovementioned aspects will provide highly significant indicators for directing Brazilian jiu-jitsu training.

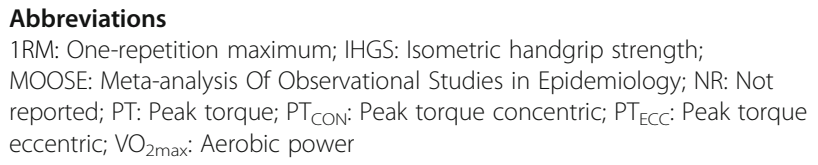

\section{Authors' Contributions}

The design of the systematic review was devised by the first author (LVA). The collection and synthesis of the data were undertaken by the first (LVA) and fourth authors (BHMB). The risk of bias assessment was completed by all authors. Data interpretation and manuscript preparation were carried out by all authors. All authors read and approved the final version of the manuscript.

\section{Competing Interests}

Leonardo Vidal Andreato, Francisco Javier Díaz Lara, Alexandro Andrade and Braulio Henrique Magnani Branco declare that they have no conflict of interest.

\section{Financial Support}

No financial support was received for the conduct of this study or preparation of this manuscript.

\section{Author details}

${ }^{1}$ Sciences Center of Health and Sport, State University of Santa Catarina, Florianopolis, Brazil. ${ }^{2}$ Faculty of Sport Sciences, Sport Training Laboratory, University of Castilla-La Mancha, Toledo, Spain. ${ }^{3}$ School of Physical Education and Sport, University of Sao Paulo, Sao Paulo, Brazil. ${ }^{4}$ University Center of Maringa - UNICESUMAR, Maringa, Parana, Brazil.

Received: 15 June 2016 Accepted: 8 December 2016

Published online: 13 February 2017

\section{References}

1. Vidal-Andreato L. Estimated aerobic power, muscular strength and flexibility in elite Brazilian Jiu-jitsu athletes. Sci Sports. 2011;26(6):329-37.

2. International Brazilian Jiu-Jitsu Federation (IBJJF). In: http://ibjjf.org/wpcontent/uploads/2015/04/RulesIBJJF_v4_en-US.pdf Accessed on 10 May 2016

3. Del Vecchio FB, Bianchi S, Hirata SM, et al. Análise morfo-funcional de praticantes de Brazilian jiu-jitsu e estudo da temporalidade e da quantificação das ações motoras na modalidade. Mov Percepção. 2007; 7(10):263-8.

4. Andreato LV, Julio UF, Gonçalves Panissa VL, et al. Brazilian jiu-jitsu simulated competition Part II: physical performance, time-motion, technicaltactical analyses, and perceptual responses. J Strength Cond Res. 2015;29(7): 2015-25.

5. Branco BHM, Fukuda DH, Andreato LV, et al. The effects of hyperbaric oxygen therapy on post-training recovery in jiu-jitsu athletes. PLoS One. 2016;11(3):e0150517.

6. Castarlenas JL, Solé J. El entrenamiento de la resistencia en los deportes de lucha con agarre: una propuesta integradora. Apunts: Educ Física Deportes. 1997; (47):81-6. 
7. Andreato LV, Santos JFS, Esteves JVDC, et al. Physiological, nutritional and performance profiles of Brazilian jiu-jitsu athletes. J Hum Kinet. 2016;53:261-71.

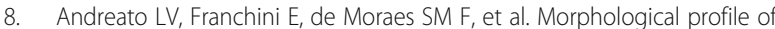
Brazilian Jiu-Jitsu elite athletes. Rev. Bras Med Esporte. 2012;18(1):46-50.

9. Brito CJ, Roas AFCM, Brito ISS, et al. Methods of body-mass reduction by combat sport athletes. Int J Sport Nutr Exerc Metab. 2012;22(2):89-97.

10. Franchini E, Del Vecchio FB, Matsushigue KA, et al. Physiological profiles of elite judo athletes. Sports Med. 2011;41(2):147-66.

11. Yoon J. Physiological profiles of elite senior wrestlers. Sports Med. 2002; 32(4):225-33.

12. Chaabène $H$, Tabben $M$, Mkaouer $B$, et al. Amateur boxing: physical and physiological attributes. Sports Med. 2015;45(3):337-52.

13. Bridge CA, Ferreira da Silva Santos J, Chaabène $H$, et al. Physical and physiological profiles of taekwondo athletes. Sports Med. 2014;44(6):713-33.

14. Chaabène $H$, Hachana $Y$, Franchini $E$, et al. Physical and physiological profile of elite karate athletes. Sports Med. 2012;42(10):829-43.

15. Stroup DF, Berlin JA, Morton SC, et al. Meta-analysis of observational studies in epidemiology: a proposal for reporting. Meta-analysis Of Observational Studies in Epidemiology (MOOSE) group. JAMA. 2000;283:2008-12.

16. Schwartz J, Takito MY, Del Vecchio FB, et al. Health-related physical fitness in martial arts and combat sports practitioners. Sport Sci Health. 2015;11(2): 171-80.

17. Franchini E, Takito MY, Bertuzzi RCM. Morphological, physiological and technical variables in high-level college judoists. Arch Budo. 2005;1:1-7.

18. Franchini $E$, Nunes AV, Moraes JM, et al. Physical fitness and anthropometrical profile of the Brazilian male judo team. J Physiol Anthropol. 2007;26:59-67.

19. Arruda L, Navarro F, Liberalli R, et al. Percentage of fat in practitioners of jiu-jitsu in the city of academies Florianópolis-SC. Rev Bras Nutr Esportiva. 2012;6(31):84-8.

20. Diaz-Lara FJ, García JMG, Monteiro LF, et al. Body composition, isometric hand grip and explosive strength leg - similarities and differences between novices. Arch Budo. 2014;10(1):211-7.

21. Coswig VS, Neves AHS, Del Vecchio FB. Características físicas e desempenho motor no jiu-jitsu brasileiro: estudo com iniciantes e experientes na modalidade. Lecturas Educación Física y Deportes (Buenos Aires), 2011(16). In: http://www.efdeportes.com/efd162/desempenho-motor-no-jiu-jitsubrasileiro.htm Accessed 10 May 2016.

22. Brandão F, Fernandes HM, Alves JV, et al. Hematological and biochemical markers after a Brazilian Jiu- Jitsu tournament in world-class athletes. Braz J Kinanthropom Hum Performance. 2014;16(2):144-51.

23. Andreato LV, Esteves JVDC, Gomes TLM, et al. Perfil morfológico de atletas de Brazilian jiu-jitsu de diferente nível competitivo. Movimento \& Percepção. 2010;11:137-45.

24. Gomes TLM, Andreato LV, Franzói de Moares SM, et al. Perfis antropométricos de atletas de elite e nãoelite de Brazilian Jiu-Jitsu. In: III Congresso Brasileiro de Metabolismo, Nutrição e Exercício. Londrina-PR: Anais do III Congresso Brasileiro de Metabolismo, Nutrição e Exercício; 2010.

25. Marinho B, Andreato LV, Follmer B, et al. Comparison of body composition and physical fitness in elite and non-elite Brazilian jiu-jitsu athletes. Science \& Sports. 2016;31(3):129-4.

26. Báez E, Franchini E, Ramírez-Campillo R, et al. Anthropometric characteristics of top-class Brazilian Jiu Jitsu athletes: Role of fighting style. Int J Morphol. 2014;32(3):1043-50.

27. Ramirez-Velez R, Argothyd R, Meneses-Echavez JF, et al. Anthropometric characteristics and physical performance of Colombian elite male wrestlers. Asian J Sports Med. 2014;5(4):e23810.

28. Gualdi-Russo E, Graziani I. Anthropometric somatotype of Italian sport participants. J Sports Med Phys Fitness. 1993;33(3):282-91.

29. Degoutte F, Jouanel P, Filaire E. Energy demands during a judo match and recovery. Br J Sports Med. 2003;37(3):245-9.

30. Franchini E, Brito CJ, Fukuda DH, et al. The physiology of judo-specific training modalities. J Strength Cond Res. 2014;8(5):1474-81.

31. Leitão da Silva MAG. Perfil comparativo de atletas de kickboxing e jiu-jitsu: Estudo multidimensional da morfologia externa, desempenhado em provas maximais de curta e média duração, força muscular e orientação para realização de objetivos. Dissertação de Mestrado, Universidade de Coimbra, Portugal, 2015.

32. Rezende RA, Santos DA, Silva-Júnior ND, et al. Phase of sports training does not affect the heart rate variability in athletes of jiu-jitsu. Rev. Soc. Cardiol. Estado de São Paulo. 2013;23(3):21-5.
33. Borges CC, Oliveira RA, Oliveira RA, et al. Respostas fisiológicas agudas na prática do jiu-jitsu ecorrelação com a capacidade aeróbia. FIEP BULLETIN 2012; 82(Special Edition):ARTICLE II.

34. Mazzocante RP, Almeida JÁ, Asano RY, et al. Validity of $1600 \mathrm{~m}$ running test to predict VO2max for jiu jitsu practitioners. Educação Física em Revista. 2011;5(2):1-9.

35. Mazzoccante RP, Sousa IRC, Moreira SR, et al. The period of the day affects the twenty-four hour blood pressure response to an acute combined exercise session in Brazilian jiu jitsu athletes. Motriz. 2015;21(3):281-9.

36. Ribeiro RL, Silva JIO, Dantas MGB, et al. High-intensity interval training applied in Brazilian Jiu-jitsu is more effective to improve athletic performance and body composition. Journal of Combat Sports and Martial Arts. 2015:1-2(6):1-5.

37. Mazzoccante RP, Sousa IRC, Asano RY, et al. Alternations at the perceptual to different combined exercise in young athletes of Jiu-jitsu. R Bras Ci e Mov. 2014;22(3):76-81.

38. Silva BVC, Marocolo Júnior M, Rogério FC, Dias IS, et al. Physical tests discriminate Brazilian jiu-jitsu practioners? R Bras Ci E Mov. 2014;22(1):92-8.

39. Andreato LV, Julio UF, Panissa VL, et al. Brazilian jiu-jitsu simulated competition Part I: metabolic, hormonal, cellular damage, and heart rate responses. J Strength Cond Res. 2015;29(9):2538-49.

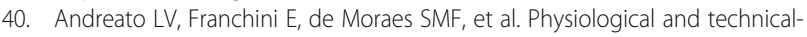
tactical analysis in Brazilian jiu-jitsu competition. Asian J Sports Med. 2013; 44(2):137-43.

41. Beneke R, Beyer T, Jachner C, et al. Energetics of karate kumite. Eur J Appl Physiol. 2004;92(4-5):518-23.

42. Doria C, Veicsteinas A, Limonta E, et al. Energetics of karate (kata and kumite techniques) in top-level athletes. Eur J Appl Physiol. 2009;107(5):603-10.

43. Campos FAD, Bertuzzi R, Dourado AC, et al. Energy demands in taekwondo athletes during combat simulation. Eur J Appl Physiol. 2012;112:1221-8.

44. Lopes-Silva JP, Silva Santos JF, Branco BH, et al. Caffeine ingestion increases estimated glycolytic metabolism during taekwondo combat simulation but does not improve performance or parasympathetic reactivation. PLoS One. 2015;10(11):e0142078.

45. Davis $P$, Leithauser $M$, Beneke $R$. The energetics of simulated $3 \times 2$ min amateur boxing. Int J Sports Physiol Perform. 2014;9:233-39.

46. Gastin PB. Energy system interaction and relative contribution during maximal exercise. Sports Med. 2001;31(10):725-41.

47. Buccheit M, Laursen PB. High-intensity interval training, solutions to the programming puzzle: Part I: cardiopulmonary emphasis. Sports Med. 2013; 43(5):313-38

48. Ravier G, Dugué B, Grappe F, et al. Impressive anaerobic adaptations in elite karate athletes due to few intensive intermittent sessions added to regular karate training. Scand J Med Sci Sports. 2009;19(5):687-94.

49. Farzad B, Gharakhanlou R, Agha-Alinejad H, et al. Physiological and performance changes from the addition of a sprint interval program to wrestling training. J Strength Cond Res. 2011;25(9):2392-9.

50. Kim J, Lee N, Trilk J, et al. Effects of sprint interval training on elite Judoists. Int J Sports Med. 2011;32(12):929-34.

51. Bonato $M$, Rampichini $S$, Ferrara $M$, et al. Aerobic training program for the enhancements of HR and VO2 off-kinetics in elite judo athletes. J Sports Med Phys Fitness. 2015;55(11):1277-84.

52. Joel GB, Paiva L, Andreato LV. Blood lactate and rate of perceived exertion in Brazilian jiu-jitsu and Submission combats. Journal of Combat Sports and Martial Arts. 2014;1-2(5):7-10.

53. Lee $\mathrm{N}$, Kim J, Hyung GA, et al. Training effects on immune function in judoists. Asian J Sports Med. 2015;6(3):e24050.

54. Inbar O, Bar-Or O, Skinner JS. The Wingate anaerobic test. Champaign: Human Kinetics; 1996

55. Ramírez-Vélez R, López-Albán CA, La Rotta-Villamizar DR, et al. Wingate anaerobic test percentile norms in colombian healthy adults. J Strength Cond Res. 2016;30(1):217-25.

56. Glaister M, Stone MH, Stewart AM, et al. The influence of recovery duration on multiple sprint cycling performance. J Strength Cond Res. 2005;19(4):831-7.

57. Villar R, Gillis J, Santana G, et al. Association between anaerobic metabolic demands during simulated Brazilian jiu-jitsu combat and Specific Jiu-Jitsu Anaerobic Performance Test: Brazilian Jiu-Jitsu combat and anaerobic performance test. J Strength Cond Res, in press.

58. Franchini E, Takito MY, Nakamura FY, et al. Tipo de recuperação após uma luta de judô e desempenho anaeróbio intermitente subseqüente. Motriz. 2001;7(1):49-52 
59. Carolyn B, Cafarelli E. Adaptations in coativation after isometric resistance training. J Appl Physiol. 1992;63:2396-402.

60. Kraemer JW, Vescovi JD, Dixon P. The physiological basis of Wrestling: Implications for conditioning programs. Strength Cond J. 2004;26(2):10-5.

61. Ratamess NA. Strength and conditioning for grappling sports. Strength Cond J. 2011:33(9):35-44.

62. Oliveira M, Moreira D, Godoy JRP, et al. Evaluation of the palmar grip strength in jiu-jitsu athletes in competitive level. R bras Ci e Mov. 2006; 14(3):63-70

63. Fry AC, Newton RU. A brief history of strength training and basic principles and concepts. In: Kraemer WJ, Häkkinen K, editors. Strength training for sport. Oxford: Blackwell Science; 2002. p. 1-19.

64. Chaabène H, Negra Y, Bouguezzi R, Hachana H. Physical and physiological attributes of wrestlers: an update. J Strength Cond Res. in press.

65. Bompa T, Half GG. Periodization: theory and methodology of training. human kinetics, 5th edition, 2001.

66. Steward T. Strength training for wrestling. NSCA Journal. 1988;10:32-5.

67. Moss BM, Refsnes PE, Abildgaard A, et al. Effects of maximal effort strengthtraining with different loads on dynamic strength, cross-sectional area, load-power and load-velocity relationships. Eur J Appl Physiol Occup Physiol. 1997;75(3):193-9.

68. Silva BV, Simim MA, Marocolo M, et al. Optimal load for the peak power and maximal strength of the upper body in Brazilian Jiu-Jitsu athletes. J Strength Cond Res. 2015;29(6):1616-21.

69. Matuzaki SS, Dechechi CJ, Miarka B. Análise da cinética da preensão manual em competidores de jiu-jitsu após uma luta. In: XXXII Simpósio Internacional de Ciências do Esporte -CELAFISCS, 2009, São Paulo. XXXII Simpósio Internacional de Ciências do Esporte -CELAFISCS, 2009.p.191.

70. Monteiro LF, Massuça LM, García García J, et al. Plyometric muscular action tests in judo- and non-judo athletes. Isokinet Exerc Sci. 2011;19:287-93.

71. Garcia-Pallares J, Lopez-Gullon JM, Muriel X, et al. Physical fitness factors to predict male Olympic wrestling performance. Eur J Appl Physiol. 2011; 111(8):1747-58.

72. Franchini E, Takito MY, Pereira JNDC. Freqüência cardíaca e força de preensão manual durante a luta de jiu-jitsu. Lecturas Educación Física y Deportes 2003; 65. In: http://www.efdeportes.com/efd65/jiujitsu.htm Accessed 10 May 2016

73. Nascimento APC. Potencialização da pós-ativação na força através do treinamento funcional em atletas de jiu jitsu. Revista Hórus. 2011;5(1):262-69.

74. Komi PV. Strength and power in sport. Oxford: Blackwell Science Ltd; 2003.

75. Silva BVC, Júnior M, Simim MAM, et al. Reliability in kimono grip strength tests and comparison between elite and non-elite Brazilian Jiu-Jitsu players. Arch Budo. 2012;8(2):103-7

76. Franchini $E$, Miarka B, Matheus L, et al. Endurance in judogi grip strength tests: Comparison between elite and non-elite judo players. Arch Budo. 2011;7(1):1-4

77. Franchini E, Branco BM, Agostinho MF, et al. Influence of linear and undulating strength periodization on physical fitness, physiological, and performance responses to simulated judo matches. J Strength Cond Res. 2015;29(2):358-67.

78. Silva BVC, Marocolo Junior M, Simim MAM, et al. Performance in kimono grip strength tests among Brazilian jiu-jitsu practitioners from different levels. Journal of Combat Sports and Martial Arts. 2014;1-2(5):11--5.

79. Krstulovic S, Zuvela F, Katic R. Biomotor systems in elite junior judoists. Coll Antropol. 2006:30(4):845-51.

80. Mirzaei B, Curby DG, Rahmani-Nia F, et al. Physiological profile of elite Iranian junior freestyle wrestlers. J Strength Cond Res. 2009;23(8):2339-44.

81. Araujo AGS, Pinheiro A, Teixeira JA. Assessment of flexibility in jiu-jitsu fighters. Lecturas Educación Física y Deportes (Buenos Aires) 2012;15(66). In: http://www.efdeportes.com/efd166/avaliacao-da-flexibilidadeem-lutadoresde-jiu-jitsu.htm Accessed 10 May 2016

82. Schmidt RA. Motor learning and performance: from principles to practice. Champaign: Human Kinetics; 1991.

83. Andrade A, Crocetta TB, Silva RB, et al. Motivation, reaction time and sociodemographic characteristics of Jiu-Jitsu beginner athletes. R Bras Ci e Mov. 2014;22(1):119-29.

84. Carter J. Body composition of Montreal Olympic athletes. In: Carter J, editor. Physical structure of Olympic athletes, part I:Montreal Olympic games anthropological project. Basel: Karger; 1982. p. 107-16.

85. Diaz-Lara FJ, Del Coso J, Portillo J, et al. Enhancement of high-intensity actions and physical performance during a simulated Brazilian jiu-jitsu competition with a moderate dose of caffeine. Int J Sports Physiol Perform. 2016;11(7):861-7.

86. Lohman TG. Advances in body composition assessment. Canada: Human Kinetics; 1992.

87. Jackson AS, Pollock ML. Generalized equations for predicting body density of men. Br J Nutr. 1978:40(3):497-504.

88. Moon JR, Smith AE, Tobkin SE, et al. Total body water changes after an exercise intervention tracked using bioimpedance spectroscopy: a deuterium oxide comparison. Clin Nutr. 2009;28(5):516-25.

89. Diaz-Lara FJ, Coso JD, García JM, et al. Analysis of physiological determinants during an international Brazilian Jiu-jitsu competition. Int J Perform Anal Sport. 2015;15:489-500.

90. Follmer B, Dellagrana RA, Franchini E, et al. Relationship of kimono grip strength tests with isokinetic parameters in jiu-jitsu athletes. Braz J Kinanthropom Hum Performance. 2015;17(5):575-82.

91. Kerr DA. An anthropometric method for fractionation of skin, adipose, bone, muscle and residual tissue masses, in males and females age 6 to 77 years. Master's Thesis. Vancouver: Simon Fraser University; 1988.

92. Carmo MCL, Marins JCB, Peluzio MCG. Nutritional intervention in jiu-jitsu athletes. R Bras Ci e Mov. 2014;22(1):99-118.

93. Lorenço-Lima L, Monteiro TS, Joel GB, et al. Exercise intensity and metabolism In Brazilian jiu-jitsu matches. Med Sci Sports Exerc. 2014;46(5 Supl 1):81.

94. Pietraszewska J, Burdukiewicz A, Stachoń A, et al. Body build and the level of development of muscle strength among male jiu-jitsu competitors and strength-trained adults. Human Movement. 2014;15(3):134-40.

95. Thorland WG, Tipton CM, Lohman TG, et al. Midwest wrestling study: prediction of minimal weight for high school wrestlers. Med Sci Sports Exerc. 1991;23(9):1102-10.

96. Pinho Júnior EA, Brito CJ, Costa Santos WO, et al. Influence of cryotherapy on muscle damage markers in jiu-jitsu fighters after competition: a crossover study. Rev Andal Med Deporte. 2014;7(1):7-12.

97. Tinsley GM, Rigby R, Gann J, et al. Frequency of eating occasions and dietary supplement use in competitive Brazilian jiu-jitsu athletes: preliminary results of an ongoing study. J Int Soc Sports Nutr. 2014;11 Suppl 1:27.

98. Andreato LV, Franzói De Moraes SM, Esteves JVDC, et al. Physiological responses and rate of perceived exertion in Brazilian jiu-jitsu athletes. Kinesiol. 2012;44(2):173-81.

99. Tipton CM, Oppliger RA. The lowa wrestling study: lessons for physicians. lowa Med. 1984;74(9):381-5.

100. Santos WOC, Brito CJ, Júnior EAP, et al. Cryotherapy posttraining reduces muscle damage markers in jiujitsu fighters. J Hum Sport Exerc. 2012;7(3): 629-38.

101. Souza-Junior TP, Pinheiro D, Almeida ALAR, et al. Kinetics of lactate removal after Brazilian jiu jitsu match. Med Sci Sports Exerc. 2012;44(Supl. 2):938-8.

102. Roas AFCM, Souza ER, Brito CJ. Prevalência de estratégias de rápida redução de massa corporal em lutadores de jiu-jítsu. In: Anais do XVI Congresso Brasileiro de Ciências do Esporte e III Congresso Internacional de Ciências do Esporte Salvador - Bahia - Brasil 20 a 25 de Setembro de. 2009.

103. Rigatto $P C$. Efeito do treinamento de potência muscular sobre o aprimoramento do perfil metabólico e do rendimento no "randori" em praticantes de jiu-jitsu. Monografia encaminhada ao Departamento de Educação Física da Faculdade de Ciências da Universidade Estadual Paulista, 2008.

104. Guedes DP, Guedes M. Composição corporal: princípios, técnicas e aplicações. 2ath ed. Londrina: APEF; 1994.

105. Slaughter $M H$, Lohman TG, Boileau RA, et al. Skinfold equations for estimation of body fatness in children and youth. Human Biol. 1988;60(5): 709-23.

106. Diaz Lara FJ, Del Coso J, Portillo J, et al. Caffeine improves muscular performance in elite Brazilian Jiujitsu athletes. Eur J Sport Sci. 2016;10:1-8.

107. Gasparotto GS, Lopes Junior EMS, Alves RC, et al. Handgrip strength in Brazilian jiu-jitsu athletes:comparative study between graduations. Cinergis. 2015;16(3):160-3.

108. Andreato LV, de Moraes SM F, Esteves JVDC, et al. Psychological, physiological, performance and perceptive responses to Brazilian jiu-jitsu combats. Kinesiol. 2014;46(1):179-85.

109. Costa RP, Oliveira FB. Mensuração da força de preensão palmar em atletas de jiu-jitsu. In: VII Congresso Goiano de Ciências do Esporte, 2011. AnápolisGO: Anais do VII CONGOCE; 2011.

110. Neto AS, Dechechi CJ. Efeito de treinamento de resistência anaeróbica específico para atletas de jiu-jitsu quanto à força de preensão manual e potência muscular. Revista Hórus. 2010;4(2):188-207. 
111. Silva BV, Ide BN, Moura Simim MA, et al. Neuromuscular responses to simulated Brazilian jiu-jitsu fights. J Hum Kinet. 2014;44:249-57.

112. Costa EC, Santos CM, Prestes J, et al. Acute effect of static stretching on the strength performance of jiujitsu athletes in horizontal bench press. Fit Perf J. 2009;8(3):212-7.

113. Fernandes IA, Santos TM, Dacol FV, et al. Effects of dehydration on strength performance of Brazilianjiujitsu fighters. R bras Ci e Mov. 2010;18(4):54-61.

114. Detanico D, Dellagrana RA, Athayde MS, et al. Effect of a Brazilian Jiu-jitsusimulated tournament on strength parameters and perceptual responses. Sports Biomech. in press.

115. Assis MMV, Gomes MI, Carvalho SEM. Quadriceps and hamstrings isokinetic evaluation in ju-jitsu athletes. Rev bras promoç saúde. 2005;18(2):85-9.

\section{Submit your manuscript to a SpringerOpen ${ }^{\circ}$ journal and benefit from:}

- Convenient online submission

- Rigorous peer review

- Immediate publication on acceptance

- Open access: articles freely available online

- High visibility within the field

- Retaining the copyright to your article

Submit your next manuscript at $>$ springeropen.com 